\title{
PROFESSOR P.P. KOPNIAIEV - SCIENTIST, PUBLIC PERSON, ESTABLISHER OF HIGHER ELECTRICAL ENGINEERING EDUCATION (to the $150^{\text {th }}$ anniversary of his birth)
}

\begin{abstract}
Purpose. To carry out complete historical and scientific analysis of Professor P.P. Kopniaiev's activities and establish his role and place of achievements in the formation of the basic concepts and directions of the theory of electrical engineering and its practical application in the development of higher education in Ukraine. Methodology. We have applied general scientific methods of logic and classification, analysis and synthesis and special historical methods - historical-comparative, problemchronological, synchronic and diachronic. Results. On the basis of generalization of a wide range of sources of central, regional and personal archives, the principles and content of scientific-pedagogical, organizational and public activities of P.P. Kopniaiev were revealed and the classification of the scientific work according to the main directions of his research was conducted. Originality. Complex analysis of P.P. Kopniaiev's scientific-pedagogical, organizational and public activities were carried out in the field of higher electrical engineering education and industrial development in Ukraine, and his scientific achievements were classified according to the main directions. Practical value. Factual information, generalizations and conclusions can be applied in the teaching of humanitarian and engineering disciplines in higher education, in particular in the development of the lecture courses and textbooks used in educational activities, as well as in the preparation of general and scientific works on the history of science and technology. References 16, figures 4.

Key words: electrical engineering science, higher education, Professor P.P. Kopniaiev, Kharkiv Polytechnic Institute.
\end{abstract}

Раскрыто процесс зарождения системы высшего электротехнической образования в Украине в конце ХІХ в. начала ХХ в. Обоснованно вклад профессора П.П. Копняева в основание научной электротехнической школь Украины. Раскрыто организационную деятельность ученого в создании электротехнического факультета Харьковского политехнического институт и первого в Украине специализированного высшего учебного заведения электротехнического профиля. Доказано, что восемь основных электротехнических направлений научных исследований, начатых П.П. Копняевым, получили развитие и стали в последующие годы отдельной научной школой или научным направлением. Библ. 16, рис. 4.

Ключевые слова: электротехническая наука, высшее образование, профессор П.П. Копняев, Харьковский политехнический институт.

Introduction. As evidenced by the experience of world and domestic science and education, a decisive role in their progress was played by prominent personalities. The formation of electrical engineering and the system of higher electrical engineering education in Ukraine is closely linked with the activities of talented electrical engineer, the organizer of science and education, Professor P.P. Kopniaiev. In different years, the scientist held the posts of Dean of the Mechanical Department, the Faculty of Electrical Engineering, the Rector of the Kharkiv Technological Institute (KhTI), the chairman of the All-Ukrainian Electrical Engineering Section and the All-Ukrainian Association of Engineers. P.P. Kopniaiev is the author of the first fundamental textbooks and manuals. $\mathrm{He}$ insisted on widespread implementation of his own developments and research results of his students, which enabled the development of the electrical engineering industry in Ukraine. It is precisely with his name that the establishment of the Department of Electrical Engineering, the Faculty of Electrical Engineering and the first specialized educational institution in Ukraine - the Kharkiv Electrical Engineering Institute - is directly connected. Scientific and organizational activities of P.P. Kopniaiev was fragmented in the publications of the students of the scientist and published before the anniversary of the Electrical Engineering Faculty of NTU «KhPI» $[1,2]$. Investigations $[3,4]$ are dedicated to the personality of Professor P.P. Kopniaiev [3, 4].

The goal of the paper is on the base of scientific literature and processing sources, primarily archival documents, to supplement the information on scientific and educational activities and biography of the famous Ukrainian electrical engineer - P.P. Kopniaiev.

The origin of electrical engineering research in Ukraine. The system of higher electrical engineering education began to be formed at the leading Universities of Ukraine in the late 19th and early 20th centuries. In Lviv Polytechnic, the beginning of electrical engineering studies is associated with the activities of Professors F. Strzheletsky and K. Olearsky. The interest in the new industry was revealed by talented engineer and scientist R. Gostkovsky. His scientific works concern the issues of electric motors, DC generators, the use of electric energy for rail transport, and so on. Further research in the field of electrical engineering was continued by Professor F. Dobzhinsky. He carried out electrical measurements, electric machines, the theory of electric circuits, and so on. As a separate educational discipline, electrical engineering was introduced into the curriculum of the Lviv Polytechnic in 1887. And in 1890 a Department of Electrical Engineering was established, headed by Professor R. Dzeslevsky, a graduate of the Technical Academy of Lviv. The expansion of the electrical engineering direction of the Lviv Polytechnic is associated with Professor S. Frise and Professor G.Z. Sokolnitsky initiated introduction of electrical engineering in Western Ukraine.

Electrical engineering at the KPI was taught by well-

known scientists: Professors M.A. Artemiev, (C) V.B. Klepikov, O.Ye. Tverytnykova 
A.V. Krukovsky, A.A. Skomorokhov, S.M. Usaty, A.A. Sokolov. At the initiative of A.V. Krukovsky an electrical laboratory was created. Professor M.A. Artemiev had a wealth of practical experience, which allowed him to become the Head of the Department of Electrical Engineering created in the KPI in 1900 and begin teaching this discipline. In 1918, in order to expand the training of engineers of new specialties, at the KPI Electrical Engineering Faculty with branches of electric power stations, electric traction and communications technology was created, but in fact nothing has changed. As before, the issue of electrical engineers was conducted in one specialization at Mechanical Department. The number of students who completed the Diploma Works on electrical engineering was five to six per year. Since 1921 the general course of electrical engineering has been expanded. Several new disciplines were introduced, including the introduction to electrical engineering, the encyclopedia of electrical engineering, the theoretical foundations of electrical engineering and the basics of the theory of alternating currents.

In 1921, the Electrical Engineering Department of the reorganized Ekaterinoslav Polytechnic Institute was attached to the Mechanical Engineering Faculty of the Ekaterinoslav Mining School. It was headed by Professor of electrical engineering G. E. Evreinov He began research in the field of electrification of mining enterprises, theoretical foundations of electrical engineering and became the founder of electromechanical specialty at the Institute. In Odessa, the Higher Courses of Telegraph Mechanics were opened in 1900. In subsequent years, the Courses were expanded and in 1923 the Odessa Electrical Engineering College of High Currents was organized. The educational institution trained communication engineers, the training period was four years. In 1929 the Electrical Engineering College was reorganized into the Faculty of Electrical Engineering of the Odessa Polytechnic Institute [3, pp. 36-40].

The organization of the physical office has become the impetus for the establishment of electrical engineering research in the Kharkiv Practical Technological Institute. On August 5, 1885 at the suggestion of V.L. Kirpichov, as Assistant Professor of physics, Associate Professor of the Kharkiv University O.K. Pogorelko was appointed by the Ministry of Public Education. Expanding the teaching of electrical engineering in the KhTI belongs to a talented electrical engineer, scientist and Professor M.P. Klobukov [4, p. 12].

Activities of P.P. Kopniaiev from to establish the Electrical Engineering Faculty and the Electrical Engineering Institute. After graduation in 1898 P.P. Kopniaiev (Fig. 1) was invited to the Kharkiv Technological Institute. All subsequent life of the scientist, with the exception of forced departure to St. Petersburg in 1905-1907, is connected with Kharkiv, with KhTI, where he was formed as a leading scientist in the field of electrical engineering and as the founder of electrical engineering education in Ukraine.

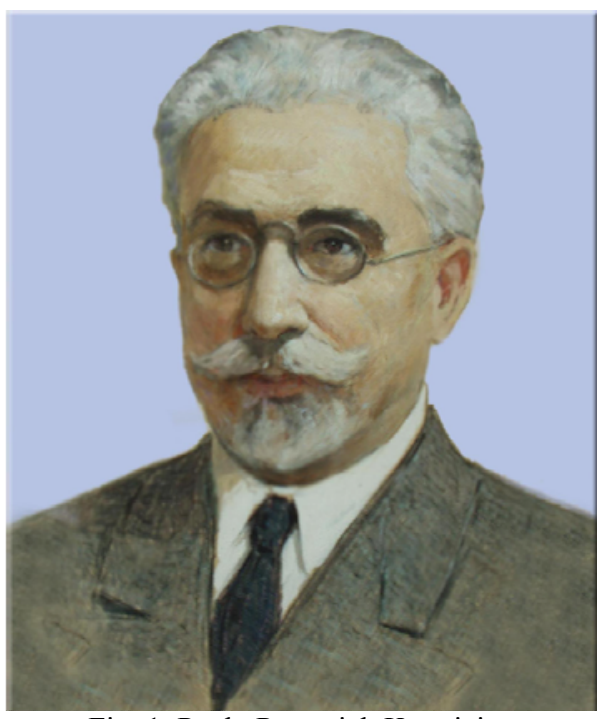

Fig. 1. Pavlo Petrovich Kopniaiev

Scientific and pedagogical activity of P.P. Kopniaiev started in KhTI at the time when the situation with the electrical engineering direction was unresolved. Educational discipline "General Electrical Engineering» was taught to students of Mechanical Department in volume of two hours per week, diploma projects on electrical specialization were not performed. There were no scientific studies either. Professor P.P. Kopniaiev immediately began reorganizing the teaching of disciplines of the electrical engineering profile. At his initiative, the number of lecture hours was increased. For the first time in the curriculum special courses were included covering various sections of electrical engineering, and, most importantly, a load was assigned for graduation design. All this created favorable conditions for the first issue, which took place already in 1900 and consisted of five specialists specializing in electrical engineering. Extension of the teaching of electrical engineering disciplines, the introduction of new electrical engineering directions, the use of new techniques, the formation of independent electrical engineering disciplines required the creation of textbooks, manuals, methodological literature. Published in 1893-1894 by the lithographic method, the textbook on general electrical engineering by M.P. Klobukov was the only textbook in Ukraine, had a small set and a number of shortcomings. Summing up the accumulated material, during 1900-1902, P.P. Kopniaiev prepared a two-part textbook for publication, which contains a full course of general electrical engineering. They became the first in Ukraine textbooks on the basics of electrical engineering. Manuals by P.P. Kopniaiev were marked by a sequence of teaching, accompanied by examples, which gave the opportunity to apply theoretical foundations for practical activities in the field of electrical engineering [5, sheets 1-2].

Creation of the Department of Electrical Engineering contributed to the expansion of the subjects of diploma projects in electrical engineering specialization and to increase the number of lectures to three hours in the first year and two - in the second. For example, in 1904/1905 academic year twenty five topics 
were worked out. It became obligatory to attend laboratory and practical classes. The term of the course in electrical engineering was completed when the exam was completed. P.P. Kopniaiev is the initiator of the introduction of new teaching methods. He submitted a request to the Institute's academic committee to allow students, in parallel with listening to lectures, to carry out laboratory work and independent projects. Before these innovations, students listened first the course of lectures, were tested and only then became practical work. After several meetings, the innovator-scientist was allowed the introduction of a new learning system [6, sheet 1].

Even at the beginning of his pedagogical activity at the Technological Institute P.P. Kopniaiev developed a project for the organization of an independent Electrical Engineering Faculty (EF). In 1907, 1912, 1914, the scientist made new attempts at its organization. On November 26, 1920, on the basis of the decision of the People's Committee of Professional Education of Ukraine, a commission under the leadership of P.P. Kopniaiev was created. The commission consisted of: lecturers of KhTI V.O. Izyurov, secretary of the commission V.M. Kyyanitsia, responsible for the construction of the laboratories Engineer V.A. Radzig and the representative of the Council of Students F.A. Stupel. The purpose of the commission was to organize an independent Electrical Engineering Faculty, to create new curricula, to supply new modern equipment. Electrical Engineering Faculty was opened on January 21, 1921. Professor P.P. Kopniaiev was appointed as Dean [2].

It should be noted that the first Electrical Engineering Faculty in Ukraine was opened at the KPI in 1918. But in fact the issue of electrical engineers was conducted only in one specialization. Diploma projects in electrical engineering 5-6 students per year performed.

The opening of the Faculty of Electrical Engineering in KhTI was very important for the development of industry in the South of Russia. P.P. Kopniaiev at the creation of the Faculty, predicting the huge demand for specialists in new electrical engineering specializations, offered accelerated releases - training for four years by separate curricula [57, p. 169].

The Faculty consisted of four Departments: «Electric Machines», «Electrical Equipment», «General Electrical Engineering», «Electric Traction». The Faculty was taught courses on the electrical equipment of factories and plants, electrification of mining industry, electric networks and lines, electric stations and city trams. The term of study was five years, industrial practice became an obligatory element of training, to the teaching of leading disciplines factory engineers were involved. The study of special courses was carried out in the measuring and electromechanical laboratories. On the proposal of Professor P.P. Kopniaiev setting up a high voltage laboratory began. Under the project of the scientist the purpose of the new laboratory was not only the educational process, but also scientific work. In the laboratory it was planned to conduct technical tests of high-voltage insulators and other insulating materials, research of high voltage lines. Accumulated by P.P. Kopniaiev during the previous years experience of training specialists contributed to the fact that already in the first year of the existence of the Faculty there was a release of highly skilled specialists. Graduate projects were carried out on the following topics: city electric tram; electrical supply of cities, district stations, electric installations for mines, equipment of electromechanical plant [7, sheets 2-4].

The Professors and lecturers of the Faculty included four Professors: O.O. Potebnya, V.M. Khrushchev, S.O. Teys and P.P. Kopniaiev and ten lecturers, including O.B. Bron, V.M. Kyyanitsia, O.Ya. Berger, M.F. Perevozsky The generalization of archival materials allows us to assert that the basis of the staff of the Faculty was graduates of the Mechanical Faculty of the KhTI, students of P.P. Kopniaiev [8, sheets $1-27$; 9 , sheets $1-2 ; 1]$.

The fruitful work of the scientist to create the Faculty of Electrical Engineering provided the grounds for the organization in 1930 of the first specialized technical institution of the electrical engineering profile in Ukraine - the Kharkiv Electrical Engineering Institute. The Institute has developed a scientific and technical school in the field of electrical engineering, where three main functions - educational, research and innovation were presented. Fundamental and applied scientific researches were conducted, based on a powerful laboratory base, and corresponded to a high scientific level. There was a close connection with production, the results of research were implemented and had economic, social significance. During this period, the first steps were taken to establish international cooperation. Scientists worked on topical issues and realized scientific developments, received world recognition.

During the 1930-1934, the teaching staff of the Institute was strengthened by highly qualified specialists. At the suggestion of P.P. Kopniaiev and V.M. Khrushchev to the posts of faculty members of the Departments experts from production, research staff of research institutions, were invited. It contributed to improving the teaching of fundamental and practical disciplines, improving the quality of teaching specialized courses and disciplines in technology of processes, strengthening the links between research Departments and production, the development of new scientific directions and the beginning of reform in the Institute of scientific electrical engineering school, strengthening the teaching potential (Fig. 2) [10, sheets 1-3].

The presence of a powerful scientific potential contributed to optimizing the structure of the Institute. The development of electrical engineering in this period took place quite rapidly, which required the creation of new Faculties with differential specialties for the training of specialists in a narrow specialization and curriculum, which differed in content. Thanks to the base, which was formed in the previous years at the Faculty of Electrical Engineering by Professor P.P. Kopniaiev, training of specialists at the Electrical Enginering Institute took place in the following directions: electrical machines, electrical apparatus, electric traction, central power stations, transmission and distribution of electric energy. So, Professor P.P. Kopniaiev was initiated and supported by his students such areas of scientific activity as fundamental and applied research in the fields of high 
voltage technology and transmission of electric energy at a distance (V.M. Khrushchev, S.M. Fertik); theory and practice of electric machines (G.I. Shturman, O.Ya. Berger); electrical apparatus (B.F. Vashura, O.B. Bron); power engineering and electric power stations (A.L. Matveev); electric drive (T.P. Gubenko, A.L. Aronov); theoretical bases of electrical engineering (O.P. Sukachev); electrical measurements (O.Kh. Khinkulov); electric traction (O.O. Potebnya).

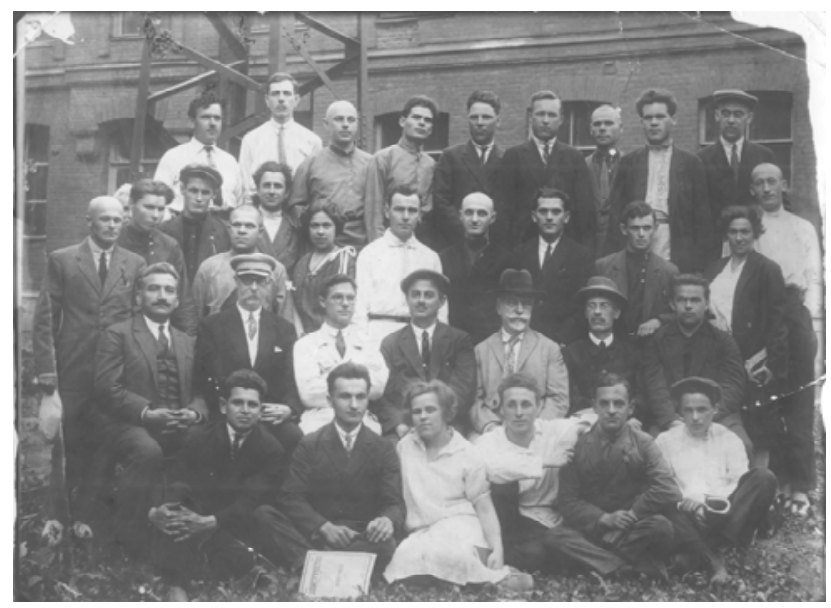

Fig. 2. The first issue of electrical engineers of the Kharkiv Electrical Engineering Institute

Research activity of P.P. Kopniaiev. The results of the initial research investigations of the scientist were published in 1896 and immediately attracted the attention of the scholars of Europe. In the work the scientist theoretically substantiated the proposed method of analogy, emphasized the unity of laws, which are essential for a particular group of phenomena, and proved that in this regard the laws have the same mathematical formulation. Unfortunately, the proposed model has not found a decent use. Meanwhile, the work of P.P. Kopniaiev in the conditions of that time was of great importance. He was the first Russian scientist, and in 1898 he laid the scientific foundations of the method of analogy in electrical engineering. This method has become widespread in modern conditions, has given us the opportunity to solve complex research problems [11].

The first specialization, which gradually began to differentiate into the discipline, became the course «Electric Machines». The machines of direct current prevailed in the installations of that time. The formation of a new course required academic literature for students and for the training of scientific staff. The analysis carried out by the author allows us to assert that the existing scientific works on the theory of electric machines of Russian and foreign scientists at that time did not meet the basic requirements for the content of discipline. The basic literature for the study of discipline at that time was the textbooks of the scientists of the German scientific school, which were considered the most experienced specialists in the field of electrical machines. But their works began to be translated only after 1908 .

In 1904, based on the materials of his own research P.P. Kopniaiev published a work devoted to questions of theory, design, research of electric machines of direct current [12]. The textbook systematized the experimental material accumulated by the author for his years in the KhTI and during internship in foreign electrical engineering high schools. The decisive factor in this work was that the scientist developed new methodological approaches to teaching the material. Without exaggeration, it should be noted that the work of P.P. Kopniaiev became the basis for the training of electrical engineers. The principles of the presentation in this section differed from other authors. The scientist considered the properties of various types of electric motors and made a complete classification of their common properties.

Next, P.P. Kopniaiev began to systematize his own teaching aids for the comprehensive training of electrical engineers. A certain group of scientific works was united by the author on the theme of the community and was a cycle of five fundamental volumes: the basis of electrical engineering, electrical measurements, DC dynamos, AC machines and transformers and electrical installations. The last volume covered the materials of disciplines, which the scientist taught in KhTI - electrical networks and electric stations. The author presents a classification and methodology for calculating wires, taking into account economic factors, their own original method of calculating illumination. He proposed several formulas for calculating the force of light (illumination) and the required component. This method had the advantage over the works of German scholars who received the result, based on empirical data or offered rather cumbersome calculations. Later, the German scientist O. Bloch created a technique similar to the P.P. Kopniaiev's one. In the second section, the author presented a development of the question of the probable increase in the load of power plants for the next decade. It was not yet elaborated and a very important issue of the operation of power plants. As the further development of power engineering showed, the scientist advanced his time with his work. In the last section P.P. Kopniaiev gives the methods of calculations of complex electric networks. Summarizing the methods known at that time, he analyzes each of them in detail, emphasizing the disadvantages and advantages.

Professor P. P. Kopniaiev made a significant contribution to the development of the direction of electric traction in Ukraine by his work on tram traction. In 1911 he, using his own experience, developed a technical project of the city electric tram in Mariupol. Based on work on traction mechanics by A.I. Lipets and D.M. Lebedev, the scientist proposed a graphical method for determining energy consumption, depending on the path profile and the tram car movement analytical equation. Unlike its predecessors, the graphical method of P.P. Kopniaiev, based on mathematical reasoning, determined the characteristics of velocity, current, time and energy consumption (that is, the corresponding graphs were constructed). Thus, there was a complete set of characteristics of the car, which determined the velocity, run time, current and the amount of electric energy consumed by the car, depending on the profile of the path. Further work was aimed at improving the methodology for calculating tram traction without graphic constructions. The result was the development of an 
analytical method, which did not depend on the graphic. This technique, proposed by P.P. Kopniaiev, it was necessary to apply in fact, in aggregate, two methods for obtaining accurate results of calculations. Technical advantage of methods of calculating tram traction of P.P. Kopniaiev was fully confirmed during the tests on existing trams $[13,14]$.

The scientific heritage of the scientist is more than fifty works and covers the main directions of development of electrical engineering at the beginning of the twentieth century. Scientific work of a scientist can be classified into six main groups. The first group consists of works from general electrical engineering, which for a long time were the basic material for the training of specialists. The second group consists of fundamental works on the theory of electric machines of constant and alternating current Studies on metrology and electrical measurements cover the third group of scientific works. The fourth group includes the work of the scientist on electric traction problems. Works on the calculations of electrical networks should be classified in the fifth group. And the last group consists of works on electric installations.

Public activities. Together with the teaching and scientific work P.P. Kopniaiev skillfully combined public activity. During 1907-1908 he was elected head of the commission for the organization of the first SouthRussian electrical engineering exhibition in Kharkiv. The purpose of the exhibition was to popularize the achievements of electrical engineering and the introduction of electrical engineering achievements in the industry, in particular, mining and agriculture. He is a permanent member of the All-Russian Electrical Engineering Congresses (Fig. 3), worked for twenty years in the leadership of the Southern Russian Society of Technologists and edited the «Proceedings» published by the society; Acting Chairman of the Electrical Engineering Section of the All-Ukrainian Association of Engineers in Kharkiv; he was a member of the International Electrical Engineering Commission. The activity of the scientist in this direction was very important for the formation of the system of training engineers and scientific workers in Ukraine, the development of the electric economy in the city of Kharkiv. In 1916 he was elected Dean of the Faculty of Mechanics. During 1919-1920, he served as Rector of KhTI [15, sheets 22; 16, sheets 1-3].

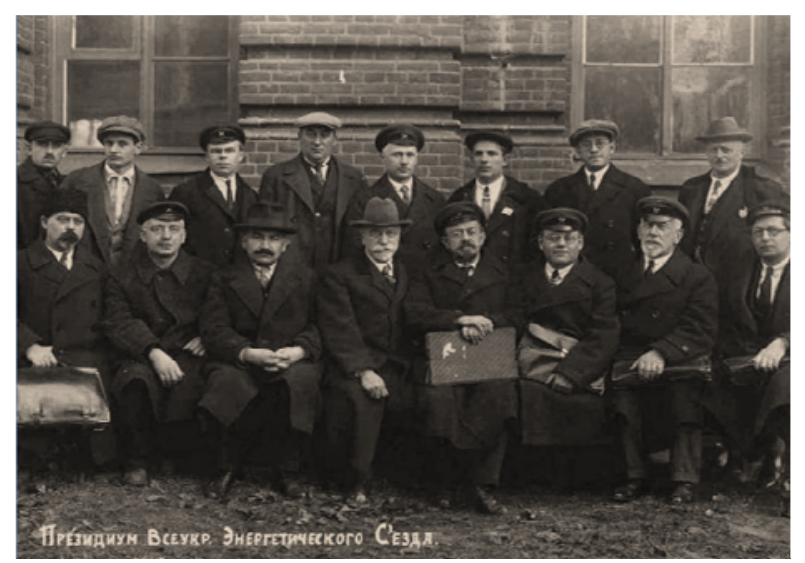

Fig. 3. Presidium of the First All-Ukrainian Energy Congress, Kharkiv, 1929
Conclusions. Certainly, Professor P.P. Kopniaiev was the founder of higher electrical engineering education and a scientific school in the field of electrical engineering in Ukraine. In the person of the scientist, the talent of the researcher, the professionalism of the educator and the natural organizational abilities are organically combined. The decisive feature of his scientific and pedagogical activity was innovation. Analysis of scientific heritage and coverage of achievements of Professor P.P. Kopniaiev suggests that he has the features of a scientific leader. So, in the 1920's in the Kharkiv Technological Institute by P.P. Kopniaiev a foundation was created for the development of the scientific and technical school of electrical engineering in the years to come.

The traditions of the founder of electrical engineering education and science are stored at NTU «KhPI». From four Departments of the Electrical Engineering Faculty created by P.P. Kopniaiev in 1921, they conduct their pedigree scientific and pedagogical collectives of about 20 Departments of four Faculties of the NTU «KhPI».

On January 21, 2011, the National Technical University «Kharkiv Polytechnic Institute» held a solemn meeting of the Academic Council devoted to the 90th anniversary of the establishment of the Faculty of Electrical Engineering and the opening of the monument to the founder of the Faculty Professor P.P. Kopniaiev.

The meeting was attended by the grandson of P.P. Kopniaiev - Professor of the M.V. Lomonosov Moscow State University, Head of the sector of the M. Keldysh Institute of Applied Mathematics, Doctor of Physical and Mathematical Sciences, professor O.D. Briuno, as well as Professor, Doctor of Physical and Mathematical Sciences G.S. Rofe-Beketov. His grandfather, Academician of architecture O.M. Beketov, together with P.P. Kopniaiev at one time headed the commission for the construction of the Electrical Engineering Building for a new Faculty (Fig. 4).

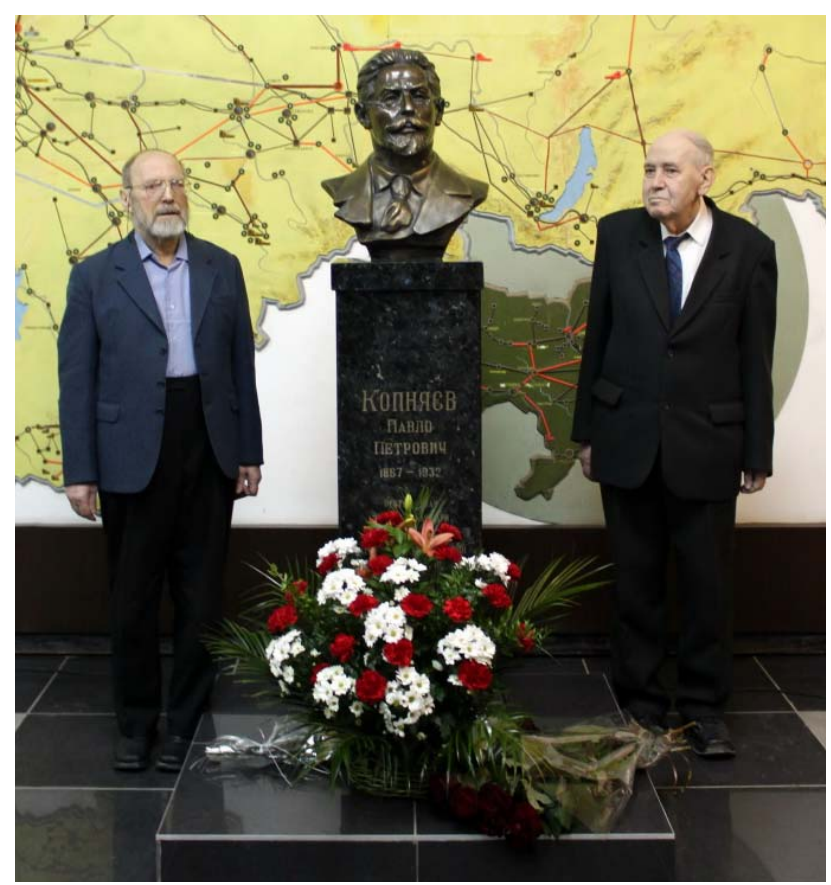

Fig. 4. O.D. Briuno and G.S. Rofe-Beketov (21.01.2011) 


\section{REFERENCES}

1. Belkind L.D. Sbornik, posvyashchennyy pamyati zasluzhennogo professora Pavla Petrovicha Kopnyaeva [Collection dedicated to the memory of the Honored Professor Pavel Petrovich Kopnyaev]. Kharkov, 1955. 135 p. (Rus).

2. Tovazhnyanskyy L.L., Tverytnykova O.Ye. Electrotechnical faculty of Kharkiv Technology Institute. Origins of development. Energy saving. Power engineering. Energy audit, 2011, no.4(86), pp. 66-74. (Ukr).

3. Tverytnykova O.Ye. Zarodzhennia $i$ rozvytok naukovotekhnichnoi shkoly Profesora P.P. Kopniaieva. Monohrafiia [The origin and development of the scientific and technical school of Professor P.P. Kopniaiev. Monograph]. Kharkiv, NTU «KhPI» Publ., 2010. 212 p. (Ukr).

4. Kameneva V.A. Pavel Petrovich Kopnyaev [P.P. Kopniaiev]. M. - L, Gosenergoizdat Publ., 1959. 96 p. (Rus).

5. Instytut arkhivoznavstva Natsionalnoi biblioteky Ukrainy im. V.I. Vernadskoho NAN Ukrainy. Fond Instytutu elektrodynamiky NAN Ukrainy 263 [Institute of Archival Studies of the National Library of Ukraine named after V.I. Vernadskyi National Academy of Sciences of Ukraine. Fund of the Institute of Electrodynamics of NAS of Ukraine 263]. Desc. 2. iss. 171,94 p. (Ukr).

6. Instytut arkhivoznavstva Natsionalnoi biblioteky Ukrainy im. V.I. Vernadskoho NAN Ukrainy. Fond IED NAN Ukrainy 263 [Institute of Archival Studies of the National Library of Ukraine named after V.I. Vernadskyi National Academy of Sciences of Ukraine. Fund of IER Foundation of the NAS of Ukraine 263]. Desc. 2. iss. 172, 114 p. (Ukr)

7. Derzhavnyi arkhiv Kharkivskoi oblasti (DAKhO). Fond R1682 Kharkivskoho politekhnichnoho instytutu [State Archives of Kharkiv Region. Fund R-1682 of Kharkiv Polytechnic Institute]. Desc. 1. iss. 83, 14 p. (Ukr).

8. Derzhavnyi arkhiv Kharkivskoi oblasti (DAKhO). Fond R1682 Kharkivskoho politekhnichnoho instytutu [State Archives of Kharkiv Region. Fund R-1682 of Kharkiv Polytechnic Institute]. Desc. 1. iss. 295, 27 p. (Ukr).

9. Arkhiv natsionalnoho tekhnichnoho universytetu «Kharkivskyi politekhnichnyi instytut» [Archive of National
Technical University «Kharkiv Polytechnic Institute»]. F.R, 1682. iss. 11,10 p. (Ukr).

10. Derzhavnyi arkhiv Kharkivskoi oblasti (DAKhO). Fond 5404 Kharkivskoho elektrotekhnichnoho instytutu [State Archives of Kharkiv Region. Fund 5404 of Kharkiv Electrotechnical Institute]. Desc. 2. iss. 59, 15 p. (Ukr).

11. Kopnyaev P.P. The analogy between the phenomena of electricity and hydraulics. Electricity, 1898, no.11-12, pp. 159166. (Rus).

12. Kopnyaev P.P. Dinamo-mashiny postoyannogo toka. Ih teoriya, ispytanie, konstruktsiya $i$ raschet (s otdelnym atlasom chertezhey) [Dynamo machines of direct current. Their theory, test, design and calculation (with a separate atlas of drawings]. Kharkov, Adolf Darre Publ., 1904. 290 p. (Rus).

13. Kopnyaev P.P. Analytical calculation of tram traction. Electricity, 1915, no 2. (Rus).

14. Kopnyaev P.P. Graphic calculation of tram traction. Electricity, 1914, no.2. . (Rus).

15. Derzhavnyi arkhiv Kharkivskoi oblasti (DAKhO). Fond 770 Kharkivskoho tekhnolohichnoho instytutu [State Archives of Kharkiv Region. Fund 770 of Kharkov Technology Institute]. Desc. 1. iss. 630, 61 p. (Ukr).

16. Derzhavnyi arkhiv Kharkivskoi oblasti (DAKhO). Fond R1682 Kharkivskoho politekhnichnoho instytutu [State Archives of Kharkiv Region. Fund R-1682 of Kharkiv Polytechnic Institute]. Desc. 1. iss. 35, 11 p. (Ukr)

Received 29.06.2017

V.B. Klepikov ${ }^{1}$, Doctor of Technical Science, Professor,

O.Ye. Tverytnykova ${ }^{1}$, Candidate of Historical Science, Associate Professor,

${ }^{1}$ National Technical University «Kharkiv Polytechnic Institute», 2, Kyrpychova Str., Kharkiv, 61002, Ukraine, phone +38057 7076226,

e-mail:klepikov@kpi.kharkov.ua, tveekhpi@ukr.net

\section{How to cite this article:}

Klepikov V.B., Tverytnykova O.Ye. Professor P.P. Kopniaiev - scientist, public person, establisher of higher electrical engineering education (to the 150th anniversary of his birth). Electrical engineering \& electromechanics, 2017, no.4, pp. 10-15. doi: 10.20998/2074-272X.2017.4.02. 